研究速報 ラット空腸一回腸バイパスモデルにおける bacterial translocation の発現と NO 産生の関係

下田 貢 山口 英見 門脇 淳 小暮 洋暉

目的：高力ロリ一輸液法 (以下, TPN) は栄養障害 の治療に著しい効果をもたらしたが，TPN施行によ る腸粘膜の萎縮は, 腸管の barrier 機能を損失させ, 細 菌やエンドトキシンの生体内侵入を許す, いわゆる bacterial translocation（以下，BT）を引き起こすと されているが, BTの発現に関してはいまだ異論が多 い. 一方, サイトカイン, エンドトキシンは, 種々の 細胞において血管拡張物質である nitric oxide（以下， NO）産生に関与していることが明らかにされている. 今回, 我々は空腸一回腸バイパスモデル (以下, JIB モ デル）を作製りしNOの発現とBTに関し検討したの で報告する。

対象と方法：Wistar 系ラット（250〜 300g）を用い ネンプタール $(40 \mathrm{mg} / \mathrm{kg})$ 腹腔内投与にて麻酔し正中 切開にて開腹した. 空腸を Treitz 靯帯から $4 \mathrm{~cm}$ 肛門 側で切離し, 回盲部から $1.5 \mathrm{~cm}$ の回腸と端側で吻合し た. 縫合糸は7-00 Proleneを用い, 全層連続縫合を 行った $(\mathrm{n}=8)$. 対照群として単開腹群を作製した $(\mathrm{n}=$ 7). 7 日目に再開腹し, 門脈より採血した. NOの代謝 産物である NO2-/NO3-は Griess 法で測定した.また, それぞれの小腸を摘出後, $1 \mu \mathrm{g}$ の total RNA を用い reverse transcription-polymerase chain reaction (以 下, RT-PCR）法で各ラット小腸内の誘導型 NOS mRNA レベルの検討を行った. 成績は F testで等分 散を確認後, Student's t-test で検定し, 危険率 $1 \%$ 以 下を持って有意差ありとした。

結果: 1) 門脈血中 NO2-/NO3-は, 単開腹群 は $32.7 \pm 3.5 \mu \mathrm{M}$ JIB 群では90.1 $27.8 \mu \mathrm{M}$ で, JIB モデ 儿群が有意差を持って上昇した $(\mathrm{p}<0.01)$ ．2）小腸内 誘導型 NOS mRNA 発現は, JIB モデル群は単開腹群 に比較して明らかにNOS MRNAの発現を認めた。 RT-PCR の対照として検討したGAPDH mRNAレ ベルには差は認められなかった(Fig. 1).3）小腸粘膜
Fig. 1 The inducible NOS mRNA expression in rat small intestine.

(1) : Molecular weight standards, (2): untreated rats, (3) : JIB model rats after 7 days.
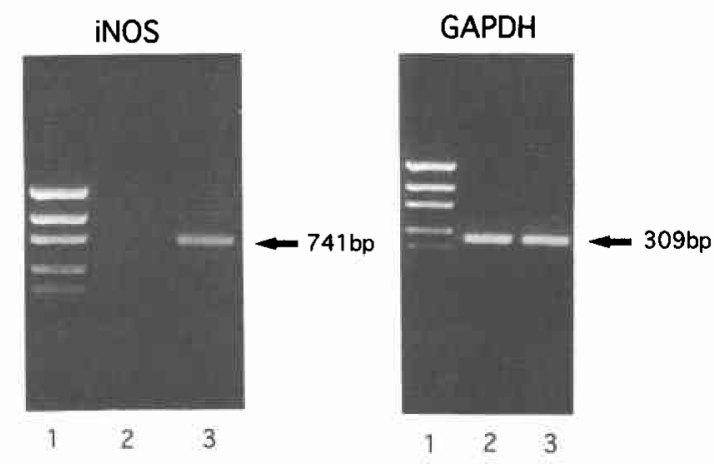

の病理組織所見では, 単開腹群と比較し明らかな緉毛 の萎縮と浮腫を認めた。

考察: $\mathrm{Ca}^{++}$非低存型である誘導型 NOS はマクロ ファージをはじめとする種々の細胞においてエンドト キシン, サイトカイン刺激により発現することが知ら れている2). 今回の JIB モデルでは, 組織学的に腸粘膜 の萎縮を認め, 腸間膜リンパ節への細菌の発現が見ら れた。腸粘膜化からの細菌やエンドトキシンの進入が 種々の細胞を活性化させ NOの産生をもたらしたと 思われ, NO の産生と NOS mRNA の発現は JIB モデ ルにおける BT の発現を示唆するものと考劣られた。

Key word : bacterial translocation

文 献：1) Jaime AR, Dan T, Tyrone $\mathrm{W}$ et al: Jejunoileal bypass-induced liver dysfunction and bacterial translocation: Effect of intraluminal Glutamine infusion. Am Surg $61: 397-402,1995$ 2) Nathan $C$ : Nitric oxide as a secretory product of mammalian cells. FASEB J 6:3051-3064, 1992

\title{
Experimental Study on Induction of Bacterial Translocation and Production of Nitric Oxide in Jejuo-ileal Bypass Model Rats
}

Mitsugi Shimoda, Hidemi Yamaguchi, Atsushi Kadowaki and Hiroaki Kogure

Second Department of Surgery, Dokkyo University School of Medicine.

$<1998$ 年 1 月 14 日受理 $>$ 別刷請求先：下田 貢

テ321-0293 栃木県下都賀郡壬生町北小林 880 獨協医科大学第 2 外科 